\title{
PENINGKATAN AKTIVITAS DAN HASIL BELAJAR SISWA DENGAN PENDEKATAN REALISTIC MATHEMATICS EDUCATION DI KELAS V.A SDN 44 KALUMBUK KOTA PADANG
}

\author{
Muhammad Nur
}

Surel: diklatpim4.90@gmail.com

\begin{abstract}
This research aims to increasing activity and the learning students using Realistic Mathematics Education (RME) approach. Objective of research covers students of classroom V.A SDN 44 Kalumbuk Kuranji District Padang City which are 30 students. This research is a classroom action research. This research was conducted on the first semester of year 2013/2014 in SDN 44 Kalumbuk Kuranji District Padang City. This research data was collected through observation, interview, note taking, video, documentation and test result. The result of data analysis showed that from oral activity, motoric, mental, and drawing the increasing from phase I to phase II. The same thing also happened on students learning outcomes, those are: (1) the average of students learning outcome of phase I is 73, 83 and it became 91,16 on phase II. Based on the the result of the research by using RME on the study of mathematics can increase the quality of education in the future.
\end{abstract}

Keywords: Activities of learning, Learning outcomes, RME

\section{PENDAHULUAN}

Matematika merupakan salah satu ilmu yang sangat penting karena matematika diajarkan mulai dari jenjang Sekolah Dasar (SD) sampai dengan perguruan tinggi. Bagi siswa selain untuk menunjang dan mengembangkan ilmu-ilmu lainnya, matematika juga dipergunakan untuk bekal terjun dan bersosialisasi dalam kehidupan masyarakat. Kurikulum 2006 menyebutkan mata pelajaran matematika perlu diberikan kepada semua siswa mulai dari SD untuk membekali siswa dengan kemampuan berfikir logis, analisis, sistematis, kritis, kreatif, serta kemampuan bekerjasama. Kompetensi tersebut diperlukan agar siswa dapat kemampuan memperoleh, mengelola, dan memanfaatkan informasi untuk bertahan hidup pada keadaan yang selalu berubah, tidak pasti, dan kompetitif (Depdiknas 2006).

Mengingat perlunya mata pelajaran matematika, seharusnya pembelajaran matematika di SD dirancang untuk menumbuhkan pemahaman siswa terhadap matematika. Guru hendaknya mampu menggunakan pendekatan pembelajaran matematika yang inovatif dan mempertimbangkan tingkat perkembangan siswa. Matematika hendaknya menjadi mata pelajaran yang menyenangkan, sehingga menimbulkan keinginan dan semangat siswa untuk mempelajarinya.

Keberhasilan pembelajaran matematika dapat diukur dari tingkat aktivitas, pemahaman, penguasaan 
materi serta hasil belajar siswa. Semakin tinggi aktivitas, pemahaman, penguasaan materi, serta hasil belajar maka semakin tinggi pula tingkat keberhasilan pembelajaran. Namun dalam kenyataannya, berdasarkan pengamatan di lapangan terhadap pembelajaran matematika khususnya pada materi luas bangun trapesium di SDN 44 Kalumbuk masih ada siswa yang kurang memahami konsep luas bangun trapesium yang diajarkan, bahkan tidak bisa menyelesaikan soal-soal luas bangun trapesium yang diberikan oleh guru, padahal soalsoal tersebut sesuai dengan materi yang sudah dipelajari.

Berdasarkan hasil observasi diketahui bahwa selama pembelajaran berlangsung, guru lebih banyak menyampaikan materi pembelajaran dengan menggunakan metode ceramah atau ekspositori, sementara siswa mencatat pada buku catatan. Pada pembelajaran tersebut guru juga cenderung memberi konsep/sifat/teorema dan cara menggunakannya sehingga pembelajaran terfokus pada guru, yang sedikit sekali memberikan kesempatan kepada siswa untuk membangun konsep matematisasi dalam diri mereka. Sehingga siswa jarang mengajukan pertanyaan walaupun guru sering meminta agar siswa bertanya jika ada materi yang belum jelas atau kurang paham. Keaktifan dalam mengerjakan soalsoal latihan juga dinilai masih kurang, serta kurangnya keberanian siswa untuk mengerjakan soal di depan kelas. Kondisi seperti ini tentu tidak dapat menumbuhkembangkan aktivitas dan hasil belajar siswa seperti yang diharapkan.

Masalah lain yang terlihat selama melaksanakan observasi adalah keaktifan siswa dalam pembelajaran yang masih kurang, hal ini diduga karena siswa belum memahami materi pelajaran yang diajarkan. Kemandirian siswa untuk belajar juga masih kurang. siswa pada umumnya belajar dengan mencatat, mendengarkan penjelasan guru. Dalam mengerjakan latihan, masih ada beberapa siswa yang kembali bertanya kepada guru tentang cara menyelesaikan soalnya, dan ada juga siswa yang hanya menunggu hasil jawaban temannya. Dari kenyataan tersebut terlihat kalau guru belum merangsang aktivitas belajar siswa secara maksimal, sehingga siswa tidak diberi kesempatan untuk mengembangkan ide-ide kreatifnya. Kenyataan seperti ini tentu berpengaruh terhadap hasil belajar yang diperoleh siswa disetiap ulangan. Hal ini dapat dilihat dari setiap ulangan harian, hasilnya masih di bawah standar ketuntasan belajar minimal yang ditetapkan oleh guru mata pelajaran yaitu 75 . Berdasarkan permasalahan di atas diperlukan suatu pendekatan dalam pembelajaran matematika, guna meningkatkan aktivitas dan hasil belajar. Salah satu pendekatan yang diharapkan dapat mengatasi hal tersebut adalah 
pendekatan Realistic Mathematics Education (RME).

\section{METODE PENELITIAN}

Pendekatan yang digunakan dalam penelitian ini adalah pendekatan kualitatif dan kuantitatif sederhana. Pendekatan ini berkenaan dengan perbaikan atau peningkatan hasil belajar pembelajaran di kelas yang diteliti. Pendekatan kualitatif digunakan untuk prosedur penelitian yang menghasilkan data deskriptif berupa kata-kata tertulis atau lisan serta perilaku yang diamati dari orang-orang atau sumber informasi, sedangkan kuantitatif digunakan untuk prosedur penelitian yang menghasilkan data berupa angka. Jenis penelitian yang dilaksanakan adalah penelitian tindakan kelas. Menurut Arikunto (2006:2) "Classroom Action Research (CAR) atau penelitian tindakan kelas merupakan sebuah penelitian yang dilakukan di kelas" selanjutnya Wardani (2007:14) mengemukakan bahwa "penelitian tindakan kelas merupakan bentuk refleksi diri, dengan tujuan untuk memperbaiki kinerja sebagai seorang guru, sehingga kemampuan belajar siswa dapat meningkat". Jenis Penelitian yang digunakan dalam penelitian ini adalah penelitian tindakan kelas (PTK). Menurut Kunandar (2008:46) "penelitian tindakan kelas adalah bentuk kegiatan refleksi diri yang dilakukan oleh para pelaku pendidikan untuk memperbaiki rasionalitas dan keadilan tentang praktik-praktik kependidikan".

Penelitian ini dilaksanakan di Kelas V.A SDN 44 Kalumbuk Kecamatan Kuranji. Peneliti memilih SDN 44 Kalumbuk sebagai tempat penelitian dengan pertimbangan bahwa: (1) sekolah ini merupakan tempat peneliti mengajar sehariharinya, (2) guru di sekolah ini memiliki wawasan dan mau berkolaborasi, serta mau menerima pembaharuan, (3) permasalahan pembelajaran matematika merupakan salah satu kendala yang dihadapi guru kelas di sekolah ini. Subjek dalam penelitian ini adalah siswa kelas V.A SDN 44 Kalumbuk Kota Padang tahun ajaran 2013/2014. Jumlah seluruh siswa ada 30 orang, yang terdiri dari laki-laki 13 orang dan perempuan 17 orang. Pelaksana pembelajaran dilakukan oleh peneliti dan guru kelas V.A sebagai observer. Penelitian ini dilaksanakan sejalan dengan proses pembelajaran yang sedang berlangsung, yakni 6 jam pelajaran dengan 2 kali pertemuan terdiri masing-masing 3x35 menit. Penelitian ini dilaksanakan pada bulan November pada semester I tahun ajaran 2013/ 2014. Penelitian ini dilaksanakan dalam 2 siklus. Pada siklus I dan II masing-masingnya 2 kali pertemuan.

Penelitian ini dirancang dengan prosedur penelitian yang meliputi langkah : perencanaan, pelaksanaan, pengamatan, dan refleksi. Rancangan peneltian tersebut dilaksanakan dalam bentuk alur penelitian. Alur penelitian 
tersebut dilaksanakan sesuai dengan prosedur penelitian yang digunakan.

\section{HASIL DAN PEMBAHASAN}

\section{Siklus I}

$\begin{array}{ccr} & \text { Siklus } & \text { I membahas } \\ \text { tentang } & \text { mengidentifikasi } & \text { ciri-ciri } \\ \text { bangun } & \text { trapesium } & \text { dan }\end{array}$
mendefenisikan pengertian bangun trapesium. Pembelajran dimulai dengan mengaitkan materi sebelumnya dengan materi yang akan dipelajari, materi tersebut akan menjembatani pengetahuan siswa dengan pengetahuan yang akan dipelajari. Pada siklus I ini siswa mengidentifikasi ciri-ciri bangun persegi dan persegi panjang untuk membantu siswa dalam mengidentifikasi ciri-ciri bangun datar trapesium, setelah mendapatkan ciri-ciri bangun trapesium siswa berdiskusi untuk mendefenisikan pengertian bangun trapesium berdasarkan ciri-ciri bangun trapesium. Selanjutnya siswa menggunakan persegi satuan untuk menemukan luas bangun trapesium. Berdasarkan kegiatan pembelajaran yang telah dilaksanakan dengan menggunakan pendekatan RME, berpengaruh terhadap peningkatan aktivtas belajar siswa ,yaitu aktivitas bertanya atau menjawab, aktivitas membuat model belajar, aktivitas menggambar media, dan aktivitas mempersentasikan. Penggunaan pendekatan RME juga berpengaruh terhadap peningkatan hasil belajar siswa yang mencapai $73,83 \%$ siswa yang dinyatakan nilainya tuntas sesuai KKM.

\section{Siklus II}

Siklus II membahas materi tentang menemukan rumus luas trapesium dan menyelesaikan masalah kontekstual yang berhubungan dengan luas trapesium. Pembelajran dimulai dengan mengingatkan kembali kepada siswa tentang ciri-ciri, defenisi, dan konsep luas luas bangun trapesium, materi tersebut akan menjembatani pengetahuan siswa dengan pengetahuan yang akan dipelajari. Pada siklus II ini siswa mencoba menemukan rumus bangun trapesium dengan menggunakan konsep luas pada bangun persegi panjang, kegiatan dimulai siswa dengan mengubah bangun persegi panjang kepada bangun trapesium, sehingga siswa menemukan rumus bangun trapesium. Setelah siswa mendapatkan rumus bangun trapesium siswa menyelesaikan soal kontekstual yang berhubungan dengan bangun trapesium. Dalam menyelesaikan soal terebut siswa menggunakan rumus bangun trapesium yang sudah didapat.

\begin{tabular}{lrr}
\multicolumn{2}{c}{ Berdasarkan } & kegiatan \\
pembelajaran & yang & telah
\end{tabular}
dilaksanakan dengan menggunakan pendekatan RME, berpengaruh terhadap peningkatan aktivtas belajar siswa, yaitu aktivitas bertanya atau menjawab, aktivitas membuat model belajar, aktivitas menggambar media, dan aktivitas mempersentasikan. Penggunaan pendekatan RME juga 
berpengaruh terhadap peningkatan hasil belajar siswa yang mencapai $91,16 \%$ siswa yang dinyatakan nilainya tuntas sesuai KKM. Berdasarkan hasil tersebut disimpulkan bahwa secara klasikal siswa telah mencapai ketuntasan.

\section{KESIMPULAN}

Berdasarkan pemaparan di atas, dapat disimpulkan:

1. Penerapan pembelajaran melalui pendekatan RME dapat meningkatkan aktivitas siswa kelas V.A SDN 44 Kalumbuk Kecamatan Kuranji Kota Padang.

2. Penerapan pembelajaran melalui pendekatan RME dapat meningkatkan hasil belajar siswa kelas V.A SDN 44 Kalumbuk Kecamatan Kuranji Kota Padang Adapun saran dalam penelitian ini ialah:

1. Pembelajaran melalui pendekatan RME dapat menjadi salah satu alternatif pembelajaran ayang akan diterapkan di sekolah-sekolah lain, untuk meningkatkan mutu pendidikan kearah yang lebih baik.

2. Guru diharapkan untuk menggunakan media peragaan yang ada disekitar lingkungan, sehingga siswa tertarik untuk mempelajarinya.

3. Guru sebaiknya membiasakan siswa untuk berani bertanya dan menjawab pertanyaan guru ataupun temannya.

4. Dalam menanamkan konsep materi, guru membawa siswa dalam kehidupan sehari-hari yang dapat dirasakan dan dibayangkan siswa.

\section{DAFTAR RUJUKAN}

Arikunto, Suharsimi dkk. 2006. Penelitian Tindakan Kelas. Jakarta: Bumi Aksara.

Aunurahman. 2009. Belajar dan Pembelajaran. Bandung: CV. Alfabeta.

Gravemeijer, Koeno. 1994. Developing Realistic Mathematics Education. Utrecht: Freudenthal Institute.

Hadi, Sutarto. 2005. Pendidikan Matematika Realistik dan Implementasinya.

Banjarmasin: Tulip.

Hamalik, Oemar. 2007. Proses Belajar Mengajar. Jakarta: PT. Bumi Aksara.

Harun, Mardiah. 1998. Pendidikan Matematika II. Bandung: UNP.

Ngalim, M. 2006. Prinsip-prinsip dan Evaluasi Pengajaran. Bandung: Remaja Rosdakarya.

Paimin, Joula Ekaningsih. 1998. Agar Anak Pintar Matematika. Jakarta: Puspa Swara.

Sudijono, Anas. 2006. Pengantar Evaluasi Pendidikan. Jakarta: PT. Raja Gafindo Persada. 